\title{
Particularities of traditional and novel atherosclerotic risk factors in women with peripheral arterial disease in a Romanian Rehabilitation Hospital
}

\author{
Dan-Horațiu Comșa ${ }^{1}$, Dumitru Zdrenghea ${ }^{2}$, Ioana Berindan-Neagoe ${ }^{1}$, Livia Budişan', Gabriel \\ Guşetu $^{1}$, Adela V. Sitar-Tăuț ${ }^{1}$, Bogdan Caloian' ${ }^{1}$, Dana Pop ${ }^{1}$
}

Corresponding author: Gabriel Gușetu, E-mail address: gusetu@gmail.com

\begin{abstract}
Introduction. The increasing prevalence of peripheral arterial disease (PAD) among women is becoming a general healthcare issue, as this populational group is still underrepresented in clinical trials and registries addressing this disease. The aim of this research is to determine women peculiarities in both classical and novel atherosclerosis risk factors in patients admitted in a Romanian Rehabilitation Hospital. Material and methods. 83 consecutive female patients with a mean age of $68.48 \pm 10.39$ years, symptomatic PAD and a pathological ankle-brachial index were included in the analysis. Data regarding the traditional and novel cardiovascular risk factors, both clinical, biological and paraclinical parameters were all registered. A subgroup of 40 subjects had novel inflammatory markers (hs-CRP, IL-6 and TNF- $\alpha$ ) measured, which were compared in a case-control manner to those of 17 agematched healthy controls. Results. Traditional risk factors most prevalent in our overall cohort were hypertension (85\%), smoking $(44.57 \%)$ and diabetes mellitus (45.7\%). Mean ankle-brachial index was $0.47 \pm 0.17$. Novel inflammatory markers were significantly higher in women with symptomatic PAD compared to healthy controls: hs-CRP $(\mathrm{p}<0.0001)$, IL-6 $(\mathrm{p}=0.0053$ and TNF- $\alpha(\mathrm{p}=0.005)$. Multivariate statistical analysis found ankle-brachial index $(A B I)-(p<0.0001)$, diastolic blood pressure $(p=0.0272)$, obesity $(\mathrm{p}=0.0445)$, LDL-cholesterol $(\mathrm{p}=0.0018)$, HDL-cholesterol $(\mathrm{p}=0.0092)$ and serum creatinine $(\mathrm{p}<0.0001)$ to be independent predictors for a more advanced PAD. 59\% of the patients exhibited critical limb ischemia on admission, while $60.24 \%$ had at least one major arterial occlusion on angiography. Percutaneous revascularization was the most employed treatment method, with $42 \%$ of subjects receiving PTA compared to $21.7 \%$ in the surgical arm. Conclusion. Women with PAD have specific clinical and biological characteristics that ultimately affect treatment modality, prescription of a rehabilitation program and outcome.
\end{abstract}

Key words: peripheral artery disease, markers, inflammation, women,

\section{INTRODUCTION}

Although the main clinical manifestations of atherosclerotic disease affecting the general population continue to be coronary artery disease (CAD) and stroke, peripheral arterial disease (PAD) has in the last few decades seen a steep rise in prevalence, becoming a global healthcare problem [1]. This is mostly due to an increasingly aging population, with PAD incidence and prevalence rising sharply $(>10 \%)$ after the age of 60 [2]. Because of this increased prevalence, the disease has become almost evenly distributed among genders, with studies suggesting that the prevalence of PAD is similar or even higher in women compared to men of the same age $[3,4,5,6]$. Understanding the specific risk factors and clinical features of peripheral artery disease in women is pivotal, as female sex turns out to have a major role in the diagnosis and therapy of the illness. It is stipulated that women with PAD are far more likely to be asymptomatic or exhibit atypical presentations compared to men [7]. Crucial in the prevention and treatment of the disease is the understanding of gender-specific risk factors for PAD. Registries have shown that both genders share similar conventional risk factors like age, smoking, diabetes mellitus and hypertension, but there are differences concerning novel atherosclerosis factors prevalence, like the C-reactive protein (CRP) for instance [8]. Therefore, the aim of this research was to characterise gender-specific atherosclerosis risk factor profile of female patients with PAD treated in a level 4 hospital.

\section{MATERIAL AND METHODS}

We included in this retrospective analysis a number of 83 consecutive women, aged $68.48 \pm 10.39$ years, admitted between January 2016 and December 2017 to the Cardiology department of The Clinical Rehabilitation Hospital in Cluj-Napoca, Romania. All were diagnosed with symptomatic PAD (intermittent claudication or critical limb ischemia) defined according to the criteria proposed by the latest ESC PAD guidelines [9]. A pathological ankle-brachial index (ABI) was defined as a value of less than 0.9 or greater than 1.4 [9]. Subjects with acute limb ischemia requiring emergency surgical intervention, those with non-atherosclerotic arterial disease or malignancy, and the ones with incomplete data were excluded from the study. Imagistic data was available for analysis in all subjects, as well as 
demographic parameters, atherosclerotic risk factors and treatment regimes, all obtained from hospital medical files. Novel inflammatory markers (high sensitivity $C$ reactive protein, interleukin 6 and tumor necrosis factor- $\alpha$ ) recorded on admission using the ELISA method (BioVendor a.s., Czech Republic) were available in a subgroup of 40 patients, which were compared as a case-control study to those taken in 17 age-matched healthy individuals. The subjects were not known to having malignancy, autoimmune pathology or active infection, which could have influenced the result. The study complied with the Helsinki Declaration of ethical principles for medical research. Statistical analysis was performed using SPSS-PC 15.0 software (SPSS Inc., Chicago IL, USA). Data is presented as mean \pm standard deviation (SD) for normally distributed variables, student t-test was used for unequal variances, as well as the hi-square test. Multivariate analysis using the stepwise method was also performed. A p-value threshold of 0.05 was set for statistical significance.

\section{RESULTS}

The baseline demographic and clinical characteristics of the cohorts are summarized in tables 1 and 2. The mean value of ABI for the main group was 0.47 . Univariate analysis in the casecontrol group found ABI, smoking, diabetes and hypertension to be significantly higher in the PAD cohort. Novel inflammatory markers measured in the subgroup of 40 patients were significantly higher than those of healthy controls, with the difference reaching high levels of statistical significance: hsCRP $\quad 10,701 \pm 2355$ vs $8,426 \pm 1802 \quad \mathrm{ng} / \mathrm{ml}$ $(\mathrm{p}<0.0001), \quad$ IL-6 $6.47 \pm 1.71$ vs $2.78 \pm 1.05 \mathrm{pg} / \mathrm{ml}$ $(\mathrm{p}=0.0053)$ and TNF- $\alpha \quad 8.93 \pm 2.32$ vs $5.32 \pm 1.49$ $\mathrm{pg} / \mathrm{ml}(\mathrm{p}=0.005)-$ fig 1,2 and 3 . Multivariate statistical analysis using the stepwise method that took into account age, sex and risk factors for PAD, found ankle-brachial index $(A B I)-(p<0.0001)$, diastolic blood pressure $(p=0.0272)$, obesity $(p=0.0445)$, LDL-cholesterol $(p=0.0018)$, HDLcholesterol $(\mathrm{p}=0.0092)$ and serum creatinine $(p<0.0001)$ to be independent predictors for a more advanced PAD (stages III and IV Leriche-Fontaine) in the overall group of 83 subjects. The analysis revealed that $\mathrm{ABI}$ and HDL-cholesterol are both strong predictors for PAD $(\mathrm{p}=0.0001$, respectively $\mathrm{p}=0.04)$. Concerning the type of clinical presentation, the majority $(59 \%)$ of female patients were admitted with critical limb ischemia, while the rest had chronic stable disease, with intermittent claudication as the main symptom.

Table 1. The demographic and biological characteristics of the main cohort.

\begin{tabular}{|l|c|}
\hline Variable & Mean \pm SD, $\%$ \\
\hline Age & $68.48 \pm 10.39$ \\
\hline Ankle-brachial index & $0.47 \pm 0.17$ \\
\hline Leriche-Fontaine stage & \\
\hline IIA & 0 \\
\hline IIB & 34 \\
\hline III & 23 \\
\hline IV & 26 \\
\hline Smoking & 37 \\
\hline Diabetes mellitus & 38 \\
\hline Arterial hypertension & 71 \\
\hline Dyslipidemia & 50 \\
\hline Obesity & 19 \\
\hline Uric acid (mg/dl) & $6.05 \pm 2.03$ \\
\hline Total cholesterol (mg/d) & $186.75 \pm 46.28$ \\
\hline Triglycerides (mg/dl) & $162.38 \pm 92.48$ \\
\hline LDL-cholesterol (mg/dl) & $109.61 \pm 40.85$ \\
\hline HDL-cholesterol (mg/dl) & $45.07 \pm 14.1$ \\
\hline Glycemia (mg/dl) & $113.35 \pm 42.44$ \\
\hline Creatinine (mg/d) & $0.98 \pm 0.55$ \\
\hline History of CAD & 20 \\
\hline Heart failure symptoms & 12 \\
\hline Prior stroke/TIA & 6 \\
\hline Location of lesion & \\
\hline suprainguinal & 34 \\
\hline infrainguinal & 49 \\
\hline Severity of lesion & 21 \\
\hline Stenosis & 50 \\
\hline Complete oclusion & 12 \\
\hline Oclusion+stenosis & \\
\hline Invasive treatment & \\
\hline Percutaneous & \\
\hline Surgical & \\
\hline Amputation & \\
\hline
\end{tabular}

Women have a tendency of often exhibiting complete occlusions on imagistic study (60.24\%), with the rest showing different degrees of stenotic lesions. Medical therapy prescribed was optimized according to PAD stages and is synthesized in table 3 . 
Table 2. General characteristics and novel inflammation makers for two subgroups.

\begin{tabular}{|c|c|c|c|}
\hline Parameter & $\begin{array}{l}\text { PAD } \\
\text { group } \\
(n=40)\end{array}$ & $\begin{array}{l}\text { Control } \\
\text { group } \\
(n=17)\end{array}$ & $\begin{array}{l}P \\
\text { value }\end{array}$ \\
\hline Mean age & $\begin{array}{l}66.16 \quad \pm \\
8.23\end{array}$ & $\begin{array}{l}65.09 \\
10.20\end{array}$ & ns \\
\hline Smokers & $29(72.5 \%)$ & $5(29.4 \%)$ & 0.01 \\
\hline Hypertension & $20(50 \%)$ & $2(11.7 \%)$ & $<0.001$ \\
\hline $\begin{array}{l}\text { Diabetes } \\
\text { mellitus }\end{array}$ & $14(35 \%)$ & $0(0 \%)$ & $<0.001$ \\
\hline Obesity & $7(17.5 \%)$ & $3(17.6 \%)$ & ns \\
\hline $\begin{array}{l}\text { Total } \\
\text { cholesterol }\end{array}$ & $\begin{array}{l}175 \pm 41.7 \\
\mathrm{mg} / \mathrm{dl}\end{array}$ & $\begin{array}{l}166.31 \pm \\
49.9 \mathrm{mg} / \mathrm{dl}\end{array}$ & ns \\
\hline $\begin{array}{l}\text { LDL- } \\
\text { cholesterol }\end{array}$ & $\begin{array}{l}105.84 \pm \\
41.0 \mathrm{mg} / \mathrm{dl}\end{array}$ & $\begin{array}{l}102.2 \pm \\
43.5 \mathrm{mg} / \mathrm{dl}\end{array}$ & ns \\
\hline $\begin{array}{l}\text { HDL- } \\
\text { cholesterol }\end{array}$ & $\begin{array}{l}41.90 \quad \pm \\
10.0 \mathrm{mg} / \mathrm{dl}\end{array}$ & $\begin{array}{l}40.16 \quad \pm \\
13.3 \mathrm{mg} / \mathrm{dl}\end{array}$ & ns \\
\hline Blood glucose & $\begin{array}{l}105.37 \pm \\
42.0 \mathrm{mg} / \mathrm{dl}\end{array}$ & $\begin{array}{l}98.3 \pm 25.8 \\
\mathrm{mg} / \mathrm{dl}\end{array}$ & ns \\
\hline Triglycerides & $\begin{array}{l}139.23 \pm \\
66.5 \mathrm{mg} / \mathrm{dl}\end{array}$ & $\begin{array}{l}131.03 \pm 68 \\
\mathrm{mg} / \mathrm{dl}\end{array}$ & ns \\
\hline ABI & $0.61 \pm 0.16$ & $1.05 \pm 0.17$ & $<0.001$ \\
\hline hs-CRP & $\begin{array}{l}10,719 \pm 21 \\
3 \mathrm{ng} / \mathrm{ml}\end{array}$ & $\begin{array}{l}8,426 \pm 180 \\
2 \mathrm{ng} / \mathrm{ml}\end{array}$ & $\begin{array}{l}<0.000 \\
1\end{array}$ \\
\hline IL-6 & $\begin{array}{l}6.47 \pm 1.71 \\
\mathrm{pg} / \mathrm{ml}\end{array}$ & $\begin{array}{l}2.78 \pm 1.05 \\
\mathrm{pg} / \mathrm{ml}\end{array}$ & 0.0053 \\
\hline TNF- $\alpha$ & $\begin{array}{l}8.93 \pm 2.32 \\
\mathrm{pg} / \mathrm{ml}\end{array}$ & $\begin{array}{l}5.32 \pm 1.49 \\
\mathrm{pg} / \mathrm{ml}\end{array}$ & 0.005 \\
\hline
\end{tabular}

Table 3. Classes of medication administered in the main group.

\begin{tabular}{|l|l|}
\hline Medication & No (\%) \\
\hline Aspirin & $63(72.41)$ \\
\hline P2Y12 inhibitor & $47(54.02)$ \\
\hline Cilostazol & $25(28.73)$ \\
\hline Pentoxifylline & $21(24.13)$ \\
\hline Statin & $80(91.95)$ \\
\hline $\begin{array}{l}\text { Prostaglandin } \\
\text { (Alprostadil) }\end{array}$ & $5(5.7)$ \\
\hline
\end{tabular}

Fig 1. hs-CRP values in the two groups

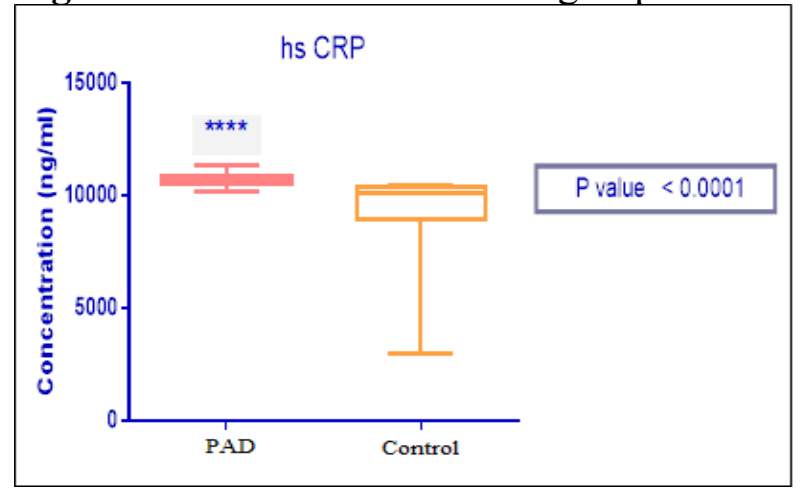

Fig 2. Human TNF- $\alpha$ values

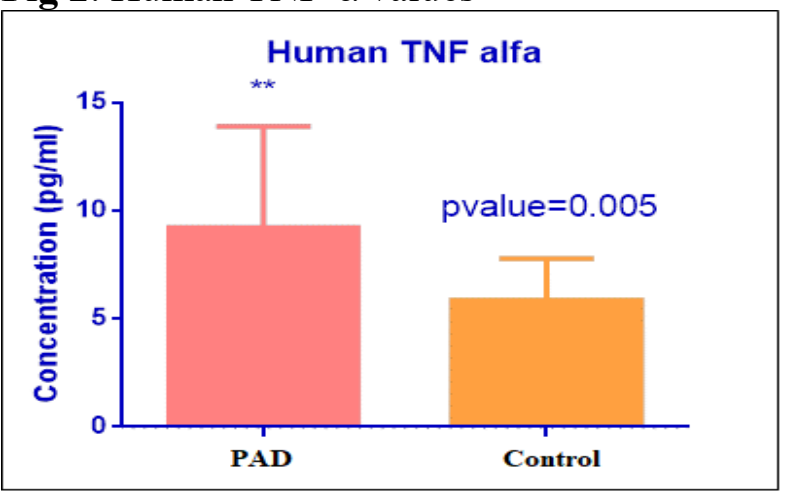

Fig 3. Human IL-6 values

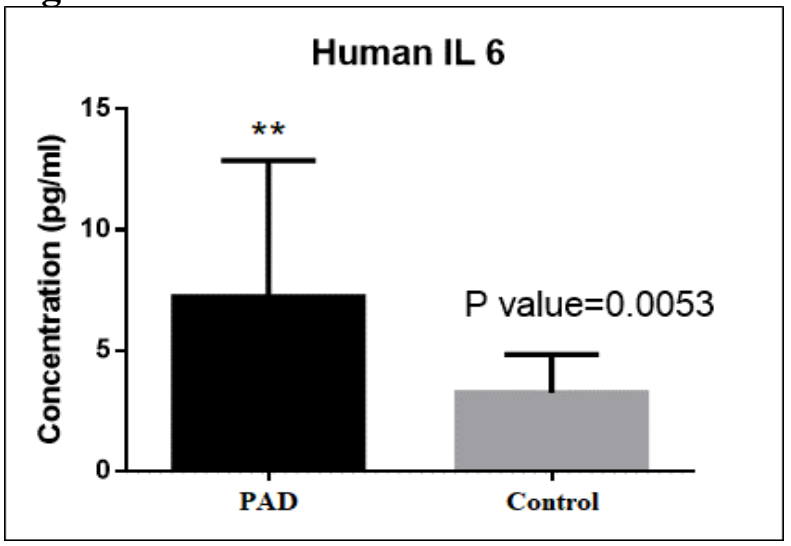


With concern to invasive treatment methods, percutaneous revascularization was the most common treatment method in our cohort, 35 (42\%) of the females benefiting form peripheral angioplasty compared to vascular bypass surgery which was offered to 18 subjects $(21.7 \%)$. The rates of limb amputation were low- $1.2 \%$. All subjects with stable PAD, regardless of treatment method, were advised on registering for supervised ambulatory rehabilitation programs. The ones who were unable had been prescribed unsupervised physical exercise regimens of at least 30 minutes of walking at least 5 days/week.

\section{DISCUSSION}

Due to

underrepresentation of female subjects in clinical trials and registries describing peripheral atherosclerosis, there is still a major gap in knowledge regarding the specific risk factors and clinical characteristics of PAD in women [10]. Add this to the well-known atypical symptoms and lack of proper screening and diagnosis in this populational group and the end-result is underdiagnosis and ill treatment [7,10]. The authors of the present research wanted to get a better picture of the specific risk factors and clinical features that characterise PAD in women, as the ones in male individuals are better studied and understood. Underlying gender-specific peculiarities might lead to a better understanding of the pathophysiology of this disease in females. Our main cohort exhibited gender particularities both in terms of risk factors for developing PAD and disease severity as well. Therefore, our experience shows men are usually more prone to be current smokers or have a history of smoking compared to females, while on the other hand diabetes mellitus is more prevalent in women. This is in line with literature data that describe sexrelated differences in risk factors for developing PAD [11]. Uric acid levels were generally within normal range in our study, although one has to consider prior treatment and the small cohort. Zhan et al proved that high uric acid was correlated with lower ABI in women at increased cardiovascular risk [12]. Concerning serum lipid levels, multivariate analysis found lower HDL-levels in women and the ankle-brachial index to be independent predictors of a more advanced peripheral atherosclerotic disease. The obvious remark that can be made considering all of this is that while men are more exposed to smoking and renal insufficiency, women more often have metabolic disorders as their main cause of atherosclerosis. Coupled with the older age on onset, one might speculate these are at least in part explained by the post-menopausal state. On the other hand, apart from the classical risk factors for atherosclerosis, the last few years have seen a rising interest in novel biomarkers, most of then bioumoral or inflammation markers [13,14]. These novel cardiovascular risk factors already play a role in the early diagnosis of ischemic heart disease in women with suspected myocardial ischemia [15]. A subgroup of patients had hs-CRP, IL- 6 and TNF- $\alpha$ measurements that were compared with those of agematched healthy controls. The values were of inflammatory markers in the disease group were significantly higher compared to those of controls, reaffirming the major pathogenetic role systemic inflammation plays in PAD [16]. In fact, a study conducted by Reena et al showed that systemic inflammation, as indicated by TNF- $\alpha$ inflammatory gene expression in circulating monocytes and serum biomarker levels, is associated with a reduced walking time in patients with PAD [17]. The difference is maintained irrespective of the stage of the disease, potentially setting these markers as a new prognostic and therapeutic target.

In terms of Leriche-Fontaine stage on diagnosis, women are significantly more likely to present with critical limb ischemia compared to men, in whom stable PAD is predominant upon first diagnosis. In the current study almost $60 \%$ of female subjects presented as critical limb ischemia. Our findings are supported by a large registry by Lo and collaborators who showed women were older and had a more advanced disease on presentation [18]. This led to a preference among interventionalists and vascular surgeons to rather perform endovascular interventions over surgical revascularization in women. The same applies to our cohort, with percutaneous therapy being the treatment of choice in females, whereas surgery was used more frequently in the male group. Newer data point to key differences in outcomes after vascular interventions, with women more prone to having worse outcomes after peripheral vascular interventions due to anthropometric and demographic characteristics [19]. This has a major impact on rehabilitation and exercise prescription, as most of women with PAD will require revascularization procedures or even amputation. 
This complicates matters as post-surgical rehabilitation is costlier and requires additional resources compared to simple exercise training indicated in chronic stable PAD. However, this should not deter the physician from actively enrolling PAD patients into rehabilitation programs, as the increase in physical activity after revascularization procedures, combined with exercise training has an impact on short-term prognosis [20].

\section{CONCLUSION}

Women with

peripheral atherosclerotic disease have peculiar characteristics in terms of specific risk factors. These have a major impact on treatment options, rehabilitation prescription and overall outcome. Thus, understanding these particularities will help to better prevent, diagnose and treat PAD in women.

Study limitations. The small number of subjects for which novel inflammatory markers were available and the absence of rehabilitation exercise follow up.

ACKNOWLEDGEMENTS. This research was financially supported by a $\mathrm{PhD}$ Research Grant (PCD 7690/28/2016) from the University of Medicine and Pharmacy "Iuliu Haţieganu", ClujNapoca, Romania.

\section{References}

1. Fowkes FG, Rudan I, Aboyans V, Denenberg JO, McDermott MM, Norman PE, Sampson UK, Williams LJ, Mensah GA, Criqui MH. Comparison of global estimates of prevalence and risk factors for peripheral artery disease in 2000 and 2010: a systematic review and analysis. Lancet. 2013;382(9901):1329-40

2. Criqui $\mathrm{MH}$, Aboyans V. Epidemiology of peripheral artery disease. Circ Res. 2015;116(9):1509-26.

3. Sigvant B, Wiberg-Hedman K, Bergqvist D, Rolandsson $\mathrm{O}$, Andersson B, Persson E, Wahlberg E. A population-based study of peripheral arterial disease prevalence with special focus on critical limb ischemia and sex differences. J Vasc Surg 2007;45:1185-91.
4. Diehm C, Schuster A, Allenberg JR, Darius H, Haberl R, Lange S, Pittrow D, von Stritzky B, Tepohl G, Trampisch HJ. High prevalence of peripheral arterial disease and co-morbidity in 6880 primary care patients: cross-sectional study. Atherosclerosis. 2004;172:95-105.

5. Moussa ID, Jaff MR, Mehran R, Gray W, Dangas G, Lazic Z, Moses JW. Prevalence and prediction of previously unrecognized peripheral arterial disease in patients with coronary artery disease: the Peripheral Arterial Disease in Interventional Patients Study. Catheter Cardiovasc Interv 2009;73:719-24.

6. He Y, Jiang Y, Wang J, Fan L, Li X, Hu FB. Prevalence of peripheral arterial disease and its association with smoking in a populationbased study in Beijing, China. J Vasc Surg 2006;44:333-8.

7. Teodorescu VJ, Vavra AK, Kibbe MR. Peripheral arterial disease in women. J Vasc Surg. 2013;57(4 Suppl):18S-26S.

8. Hiramoto JS, Katz R, Weisman S, Conte M. Gender-specific risk factors for peripheral artery disease in a voluntary screening population. J Am Heart Assoc. 2014;3(2):e000651.

9. Aboyans V, Ricco JB, Bartelink ML, Björck M, Brodmann M, Cohnert T, Collet JP, Czerny M, De Carlo M, Debus S, EspinolaKlein C, Kahan T, Kownator S, Mazzolai L, Naylor AR, Roffi M, Röther J, Sprynger M, Tendera M, Tepe G, Venermo M, Vlachopoulos C, Desormais I, Document Reviewers, Widimsky P, Kolh P, Agewall S, Bueno H, Coca A, De Borst GJ, Delgado V, Dick F, Erol C, Ferrini M, Kakkos S, Katus HA, Knuuti J, Lindholt J, Mattle H, Pieniazek P, Piepoli MF, Scheinert D, Sievert H, Simpson I, Sulzenko J, Tamargo J, Tokgozoglu L, Torbicki A, Tsakountakis N, Tunón $\mathrm{J}$, de Ceniga $\mathrm{MV}$, Windecker $\mathrm{S}$, Zamorano JL. 2017 ESC Guidelines on the Diagnosis and Treatment of Peripheral Arterial Diseases, in collaboration with the European Society for Vascular Surgery (ESVS). Eur J Vasc Endovasc Surg. 2017 Aug 26. pii: S1078-5884(17)30454-9 
10. Hirsch AT, Allison MA, Gomes AS, Corriere MA, Duval S, Ershow AG, Hiatt WR, Karas RH, Lovell MB, McDermott MM, Mendes DM, Nussmeier NA, Treat-Jacobson D. A call to action: women and peripheral artery disease: a scientific statement from the American Heart Association. Circulation. 2012;125(11):1449-72.

11. Hiramoto JS, Katz R, Ix JH, Wassel C, Rodondi N, Windham BG, Harris T, Koster A, Satterfield S, Newman A, Shlipak MG. Sex differences in the prevalence and clinical outcomes of subclinical peripheral artery disease in the Health, Aging, and Body Composition (Health ABC) study. Vascular. 2014;22(2):142-8.

12. Zhan Y, Dong Y, Yu J. Uric Acid and Peripheral Arterial Disease. Angiology. 2015;66(7):693.

13. Matsushita K, Kwak L, Yang C, Pang Y, Ballew SH, Sang Y, Hoogeveen RC, Jaar BG, Selvin E, Ballantyne CM, Sharrett AR, Folsom AR, Heiss G, Coresh J, Hirsch AT. High-sensitivity cardiac troponin and natriuretic peptide with risk of lowerextremity peripheral artery disease: the Atherosclerosis Risk in Communities (ARIC) Study. Eur Heart J. 2018;39(25):2412-2419.

14. Comşa H, Zdrenghea D, Man SC, Pop D. The role of novel atherosclerosis markers in peripheral artery disease: is there a gender difference? Cardiovasc J Afr. 2018;29:1-10.
15. Pop D, Dădârlat A, Zdrenghea D. Novel cardiovascular risk markers in women with ischaemic heart disease. Cardiovasc J Afr. 2014;25(3):137-41.

16. Mozos I, Malainer C, Horbańczuk J, Gug C, Stoian D, Luca CT, Atanasov AG. Inflammatory Markers for Arterial Stiffness in Cardiovascular Diseases. Front Immunol. 2017;8:1058.

17. Pande RL, Brown J, Buck S, Redline W, Doyle J, Plutzky J, Creager MA. Association of monocyte $\mathrm{TNF} \alpha$ expression and serum inflammatory biomarkers with walking impairment in PAD. J Vas Surg. 2015;61(1):155-161.

18. Lo RC, Bensley RP, Dahlberg SE, Matyal R, Hamdan AD, Wyers M, Chaikof EL, Schermerhorn ML. Presentation, treatment,and outcome differences between men and women undergoing revascularization or amputation for lower extremity peripheral arterial disease. J Vasc Surg. 2014;59(2):409418.e3.

19. Brinza K, Sex-related differences in outcomes after vascular interventions. Vasc Med. 2018;1358863X1879010. doi $10.1177 / 1358863 X 18790105$.

20. Otsuka S, Morisawa T, Yuguchi S, Hojo Y, Matsuo T, Nakajima M, Ishida A, Takahashi T. Heart Vessels. 2017;32(2):143-148. 